\title{
Front Matter: Volume 9481
}

, "Front Matter: Volume 9481," Proc. SPIE 9481, Image Sensing Technologies: Materials, Devices, Systems, and Applications II, 948101 (15 June 2015); doi: 10.1117/12.2197709

SPIE Event: SPIE Sensing Technology + Applications, 2015, Baltimore, MD, United SPIE. States 


\section{PROCEEDINGS OF SPIE}

\section{Image Sensing Technologies: Materials, Devices, Systems, and Applications II}

Nibir K. Dhar

Achyut K. Dutta

Editors

22-23 April 2015

Baltimore, Maryland, United States

Sponsored and Published by

SPIE 
The papers included in this volume were part of the technical conference cited on the cover and title page. Papers were selected and subject to review by the editors and conference program committee. Some conference presentations may not be available for publication. The papers published in these proceedings reflect the work and thoughts of the authors and are published herein as submitted. The publisher is not responsible for the validity of the information or for any outcomes resulting from reliance thereon.

Please use the following format to cite material from this book:

Author(s), "Title of Paper," in Image Sensing Technologies: Materials, Devices, Systems, and Applications II, edited by Nibir K. Dhar, Achyut K. Dutta, Proceedings of SPIE Vol. 9481 (SPIE, Bellingham, WA, 2015) Article CID Number.

ISSN: 0277-786X

ISBN: 9781628415971

Published by

SPIE

P.O. Box 10, Bellingham, Washington 98227-0010 USA

Telephone +1 3606763290 (Pacific Time) · Fax +1 3606471445

SPIE.org

Copyright (@ 2015, Society of Photo-Optical Instrumentation Engineers.

Copying of material in this book for internal or personal use, or for the internal or personal use of specific clients, beyond the fair use provisions granted by the U.S. Copyright Law is authorized by SPIE subject to payment of copying fees. The Transactional Reporting Service base fee for this volume is $\$ 18.00$ per article (or portion thereof), which should be paid directly to the Copyright Clearance Center (CCC), 222 Rosewood Drive, Danvers, MA 01923. Payment may also be made electronically through CCC Online at copyright.com. Other copying for republication, resale, advertising or promotion, or any form of systematic or multiple reproduction of any material in this book is prohibited except with permission in writing from the publisher. The CCC fee code is 0277-786X/15/\$18.00.

Printed in the United States of America.

Publication of record for individual papers is online in the SPIE Digital Library.

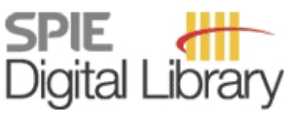

SPIEDigitalLibrary.org

Paper Numbering: Proceedings of SPIE follow an e-First publication model, with papers published first online and then in print. Papers are published as they are submitted and meet publication criteria. A unique citation identifier (CID) number is assigned to each article at the time of the first publication. Utilization of CIDs allows articles to be fully citable as soon as they are published online, and connects the same identifier to all online, print, and electronic versions of the publication. SPIE uses a six-digit CID article numbering system in which:

- The first four digits correspond to the SPIE volume number.

- The last two digits indicate publication order within the volume using a Base 36 numbering

system employing both numerals and letters. These two-number sets start with 00, 01, 02, 03, 04, $05,06,07,08,09,0 A, 0 B \ldots$. 0Z, followed by 10-1Z, 20-2Z, etc.

The CID Number appears on each page of the manuscript. The complete citation is used on the first page, and an abbreviated version on subsequent pages. 


\title{
Contents
}

\author{
$\checkmark$ Authors \\ vii Conference Committee
}

\section{SESSION 1 ADVANCED FOCAL PLANE ARRAY TECHNOLOGIES}

948102 Integration of optical functionality for image sensing through sub-wavelength geometry design (Invited Paper) [9481-1]

948105 Development of high performance SWIR InGaAs focal plane array [9481-4]

948106 Functionalized fluorescent silver nanoparticle surfaces for novel sensing and imaging techniques [9481-5]

948107 SWIR photodetector development at Fraunhofer IAF [9481-6]

\section{SESSION 2 NOVEL TECHNOLOGIES FOR IMAGING}

948108 UV/VIS/NIR imaging technologies: challenges and opportunities (Invited Paper) [9481-7]

948109 Nanopillar optical antenna nBn detectors for subwavelength infrared pixels [9481-8]

9481 OA Improved optical resonance in mid-infrared GaAs-based modulating retro-reflectors [9481-9]

\section{SESSION $3 \quad$ IMAGING SYSTEMS AND APPLICATIONS}

9481 OD Hybrid approach to mean-variance and photon transfer measurement [9481-12]

9481 OE Advanced computational sensors technology: testing and evaluation in visible, SWIR, and LWIR imaging [9481-13]

9481 OG The application of machine learning in multi sensor data fusion for activity recognition in mobile device space [9481-15]

\section{SESSION 4 IMAGING APPLICATIONS}

$9481 \mathrm{OH}$ Uncooled LWIR imaging: applications and market analysis (Invited Paper) [9481-16]

9481 ol Advanced illumination control algorithm for medical endoscopy applications [9481-17]

9481 OK Information content capabilities of very high resolution optical space imagery for updating GIS database [9481-19] 
9481 OL Aliasing removing of hyperspectral image based on fractal structure matching [9481-20]

9481 OM A low noise low power 512×256 ROIC for extended wavelength InGaAs FPA [9481-21]

9481 ON A telephoto camera system with shooting direction control by gaze detection [9481-22]

$94810 Q$ Imaging by electromagnetic induction with resonant circuits [9481-25]

9481 OR Illumination modelling of a mobile device environment for effective use in driving mobile apps [9481-26]

9481 OS Surface plasmon resonance (SPR) in a chemically etched ZnSe substrate and its effect on the Raman signal enhancement [9481-27]

9481 OT Effect of high energy proton implantation on the device characteristics of InAIGaAscapped InGaAs/GaAs quantum dot based infrared photodetectors [9481-28]

9481 OU A detail investigation on quaternary and ternary capped strain coupled quantum dots based infrared photodetectors and effect of rapid thermal annealing temperature [9481-29]

9481 OV Studies on abrupt and gradual band gap hole barriers in InAs/GaSb superlattice long wavelength photodetectors [9481-30]

9481 OW Automated optical system alignment and low order wavefront sensing [9481-31]

$94810 X \quad F l u o r e s c e n c e$ of quantum dots on e-beam patterned and DNA origami substrates [9481-32]

948111 Choosing the right video interface for military vision systems [9481-36]

948112 Nanomolecular gas sensor architectures based on functionalized carbon nanotubes for vapor detection [9481-37]

948113 Non-uniformity correction with temperature influence compensation in microbolometer detector [9481-54]

948114 High-sensitivity active pixel sensor with a variable threshold photodetector [9481-55] 


\title{
Authors
}

Numbers in the index correspond to the last two digits of the six-digit citation identifier (CID) article numbering system used in Proceedings of SPIE. The first four digits reflect the volume number. Base 36 numbering is employed for the last two digits and indicates the order of articles within the volume. Numbers start with 00, 01, 02, 03, 04, 05, 06, 07, 08, 09, OA, OB...0Z, followed by 10-12, 20-2Z, etc.

\author{
Adebimpe, David, 12 \\ Adhikary, S., OU \\ Aidam, R., 07 \\ Akins, Daniel L., 12 \\ Alkan, Mehmet, OK \\ Bae, Myunghan, 14 \\ Bai, Zhizhong, OV \\ Balgarkashi, A., OU \\ Bartlett, Paul, OQ \\ Bez, Helmut E., OR \\ Bieszczad, Grzegorz, 13 \\ Bolla, Brett M., OD \\ Bregman, Jeremy, 05 \\ Bronner, W., 07 \\ Catrysse, Peter B., 02 \\ Chakrabarti, S., OT, OU \\ Chen, Jianxin, OV \\ Chen, YU, OM \\ Choi, Byoung-Soo, 14 \\ Corrigan, Timothy D., OX \\ Culhane, Kyle M., 06 \\ Dhar, Nibir K., 05 \\ Dutta, Achyut K., 05 \\ Edirisinghe, Eran A., OG, OR \\ Fang, Jiaxiong, $\mathrm{OM}$ \\ Fang, Joyce, OW \\ Farrell, Alan, 09 \\ Ghadi, H., OT, OU \\ Gogler, Sławomir, 13 \\ Guilizzoni, Roberta, OQ \\ Hachisu, Takumi, ON \\ $\mathrm{He}, \mathrm{Li}, \mathrm{OV}$ \\ Heussen, H., 07 \\ Hines, Deon, 12 \\ Hsieh, Nick, 09 \\ Huang, Songlei, OM \\ Huang, Zhangcheng, $\mathrm{OM}$ \\ Huffaker, Diana L., 09 \\ Hung, Chung Hong, 09 \\ Ikpe, Stanley, OA \\ Islam, Syed K., OS \\ Jacobsen, Karsten, OK \\ Jacquot, Blake C., OD \\ Jin, Chuan, OV \\ Jo, Sung-Hyun, 14 \\ Kessinger, Matthew, OX \\ Kidd, Jesse, OX \\ Kleinow, P., 07 \\ Krupiński, Michał, 13
}

Kuroda, Rihito, 08

Lee, Wook-Jae, 09

$\mathrm{Li}, \mathrm{TaO}, 0 \mathrm{M}$

Lombardi, John R., OS

Lyu, Hong-Kun, 14

Madura, Henryk, 13

Maguire, Sean, OD

Mandal, A., OT

Marhoubi, Asmaa H., OG, OR

Mizuno, Genki, 05

Morgado-Dias, F., Ol

Moug, Richard, OS

Nagi, Richie, 05

Neff, David, OX

Norton, Michael L., OX

Oduor, Patrick, 05

Olah, Robert, 05

Pal, D., OT

Phillips, John, 11

Pinchuk, Anatoliy O., 06

Pouliquen, Philippe, $0 \mathrm{E}$

Rahman, Masudur, OX

Renzoni, Ferruccio, OQ

Rizk, Charbel G., OE

Rümmeli, Mark H., 12

Rutz, F., 07

Santos, Pedro, 01

Saravi, Sara, OG, OR

Savransky, Dmitry, OW

Senanayake, Pradeep, 09

Shetty, S., OU

Shin, Jang-Kyoo, 14

Sieck, A., 07

Singh, P., OT

Sousa, Ricardo M., Ol

Spendier, Kathrin, 06

Subrahmanyam, N. B. V., OT

Sugawa, Shigetoshi, 08

Takasawa, Satomi, $\mathrm{OH}$

Tamargo, Maria, OS

Teraya, Daiki, ON

Triplett, Gregory, OA

Upadhyay, S., OT

Walther, M., 07

Wang, Fangfang, OV

Wäny, Martin, Ol

Watson, Joseph C., OQ

Wei, Ran, OL

Wilson, John P., OE 
$\mathrm{Xu}$, Zhicheng, OV

Yendo, Tomohiro, ON

Zhang, Henan, 12

Zhang, Junping, $\mathrm{OL}$

Zhang, Ye, $\mathrm{OL}$

Zhou, Yi, OV

Proc. of SPIE Vol. $9481948101-6$

Downloaded From: https://www.spiedigitallibrary.org/conference-proceedings-of-spie on 26 Apr 2023 Terms of Use: https://www.spiedigitallibrary.org/terms-of-use 


\title{
Conference Committee
}

\author{
Symposium Chair
}

Wolfgang Schade, Clausthal University of Technology and Fraunhofer Heinrich-Hertz Institute (Germany)

Symposium Co-chair

Ming C. Wu, University of California, Berkeley (Unites States)

Conference Chairs

Nibir K. Dhar, U.S. Army Night Vision \& Electronic Sensors Directorate (United States)

Achyut K. Dutta, Banpil Photonics, Inc. (United States)

Conference Program Committee

Homayoon Ansari, Jet Propulsion Laboratory (United States)

Arvind I. D'Souza, DRS Sensors \& Targeting Systems, Inc. (United States)

Ravi Dutt, Booz Allen Hamilton Inc. (United States)

Michael D. Gerhold, U.S. Army Research Office (United States)

John E. Hubbs, Ball Aerospace \& Technologies Corporation (United States)

Nobuhiko P. Kobayashi, University of California, Santa Cruz (United States)

Sanjay Krishna, The University of New Mexico (United States)

Robert Olah, Banpil Photonics, Inc. (United States)

Adam Piotrowski, VIGO Systems S.A. (Poland)

Siva Sivananthan, EPIR Technologies, Inc. (United States)

Krishna Swaminathan, Intel Corporation (United States)

Rama Venkatasubramanian, RTI International (United States)

Priyalal S. Wijewarnasuriya, U.S. Army Research Laboratory

(United States)

\section{Session Chairs}

1 Advanced Focal Plane Array Technologies

Nibir K. Dhar, U.S. Army Night Vision \& Electronic Sensors Directorate (United States)

Achyut K. Dutta, Banpil Photonics, Inc. (United States) 
2 Novel Technologies for Imaging

Achyut K. Dutta, Banpil Photonics, Inc. (United States)

Nibir K. Dhar, U.S. Army Night Vision \& Electronic Sensors Directorate (United States)

3 Imaging Systems and Applications

Rihito Kuroda, Tohoku University (Japan)

4 Imaging Applications

Achyut K. Dutta, Banpil Photonics, Inc. (United States)

Rihito Kuroda, Tohoku University (Japan) 